\title{
モバイルゲームにおける女性キャラクターの魅力的要素の分析
}

\section{Analysis of Attractive Elements of Female Characters in Mobile Games}

\author{
宇田朗子 ${ }^{*}$, 村井源 ${ }^{2}$ \\ Akiko UDA $^{1 *}$, Hajime MURAI ${ }^{2}$
}

1 株式会社エイチ・アイ・ディ

HID Co., Ltd.

厂060-0003 札幌市中央区北3条西 $2 丁$ 目 10 番地 2 札幌HSビル

2 公立はこだて未来大学

Future University HAKODATE

厂041-8655 北海道函館市亀田中野町116-2

*連絡先著者 Corresponding Author

これまでキャラクターに関する研究において, 外見についての研究や男性キャラクターに の夕着目した研究は行われてきたが外見以外の魅力に着目した研究や女性キャラクターにの みに着目した研究はあまり行われていない. 本研究ではキャラクターの誘因魅力と継続魅力 の違いに着目し，女性キャラクターの魅力についての分析を行った。キャラクターのどのよ うな要素に魅力を感じているかアンケートを行い，回答を収集した．アンケートの結果を用 いてカイ二乗検定を行い, 誘因魅力と継続魅力に魅力的要素の違いに有意な差があることが 明確になった。 また，アンケート結果を用いて因子分析を行い，どのような要素の組み合わ せに魅力を感じるかを調査した．結果として，キャラクターを印象付ける要素が誘因魅力， あとから追加できる要素が継続魅力として有力であることが分かった.

In character research, research on appearance and research focusing only on male characters have been conducted. However, research focusing on attractiveness other than appearance and research focusing only on female characters have not been conducted much. In this research, we focus on the difference between the incentive attractiveness of a character and the continuous attractiveness of characters, and analyze the attractiveness of a female character. First, we investigated how attractive female characters are by questionnaire. Chi-square test and factor analysis were performed using the results of this questionnaire. Chi-square test revealed there was significant difference between incentive attractiveness and continuous attractiveness. In addition, factor analysis was performed to find out which combination of factors was attractive. Incentive attractiveness was an element that impressed the character, and continuous attractiveness was an element that could be added later to the character settings. As a future task, it is necessary to investigate whether similar results will be obtained with other mobile games.

キーワード: キャラクター, モバイルゲーム, アニメ, 漫画, アンケート

Character, Mobile game, Anime, Comic, Questionnaire 


\section{1 序論}

モバイルゲームとは携帯電話やスマー トフォン等を用いて遊ぶことができるゲ ームである。モバイルゲームとは携帯電話 やスマートフォン等を用いて遊ぶことがで きるゲームである．株式会社三菱総合研究 所のスマホゲームに関するアンケート結 果によると，モバイルゲームに課金をす る理由で最も多いものは欲しいキャラク ターやアイテムが存在するためであり [1]，キャラクターはモバイルゲーム上に おいてユーザーに課金させる重要な要素 であるといえる。 また，モバイルゲーム は運営されていく中で様々な要素が追加 され発展していくという特徵をもつ. そ のため，モバイルゲームに登場するキャ ラクターにも様々な追加要素が存在し, その要素が追加されるたびに, キャラク ターの魅力に感じる要素も増えていくと 考えた. そのため, キャラクターを好き になるきっかけの魅力的要素とキャラク ターを好きでいさせる魅力的要素に違い があると仮定した。本研究ではキャラク ターを好きになるきっかけの魅力的要素 を誘因魅力，キャラクターを好きでいさ せる魅力的要素を継続魅力と名付け, こ の 2 つの違いに着目し, どのような要素 を持つ女性キャラクターが魅力的である かを明確にすることを目的とする。

\section{2 関連研究}

キャラクターの外見に関する研究として, 漫画の登場人物の顔の分析 [2]やアニメキ ヤラクター評価のための外見の特徵抽出 [3]，キャラクターの縦横比から受ける印 象についての研究 [4]が行われている。ま
たキャラクターのセリフや性格を用いた 性格推定 [5]や少年漫画におけるキャラク ターの魅力的要素の分析 [6]などキャラク ターに関する研究が行われている.

このようにキャラクターの魅力につい ての研究は行われているが，女性キャラク ターのみに着目した研究やモバイルゲー ムのキャラクターに関する研究はあまり 行われていない.

\section{3 分析対象}

分析対象として,『アイドルマスターシ ンデレラガールズ[7]』を選定した。『ア イドルマスターシンデレラガールズ』は 190 人の女性キャラクターを有しており， 様々な魅力的要素を抽出できると期待で きる.また，『アイドルマスターシンデレ ラガールズ』のモバイルゲームである『ア イドルマスターシンデレラガールズスタ ーライトステージ[8]』はアプリの総ダウ ンロード数が 2500 万を超えている. 加え て,『アイドルマスターシンデレラガール ズ』は 9 年, 『アイドルマスターシンデレ ラガールズスターライトステージ』は 5 年という長期間サービスが継続し続けて いるため人気や知名度が高いと推測され る.よって, 本研究の目的に沿った分析 対象であると考えられる。

\section{4 手法}

\section{1 アンケートの実施}

作品のファンがキャラクターのどのよ うな要素に魅力を感じるか詳細に知るた め, 対象作品を知っている人を対象にネ ット上でアンケートを実施した。表 1 に アンケート内容を示す. 
アンケートは 2020 年 10 月 6 日から 10 月 18 日までの 2 週間実施し 2631 件の回 答が集まった。そのうち，回答が重複し ているものを除いた 2603 件からキャラ クターのどのような要素に魅力を感じて いるかを分析した。

表 1 アンケートの質問項目

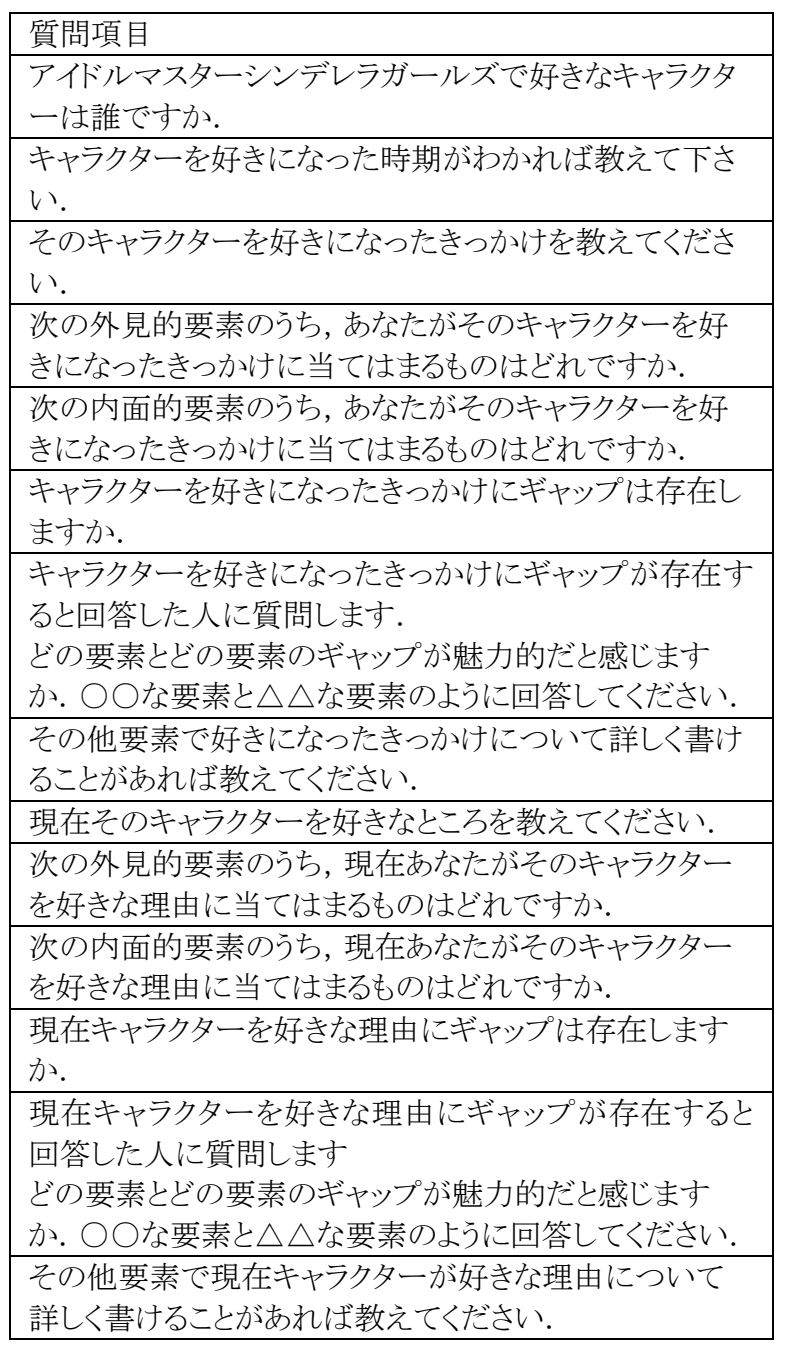

\section{2 アンケート結果の分析}

アンケート結果よりキャラクターの魅力 を分析するため, カイ二乗検定と因子分析 を行った. カイ二乗検定はキャラクターの 誘因魅力と継続魅力に差異があることを 明確にするために行った. 因子分析は魅力 を感じる要素の組み合わせを調べるため
に行った.

\section{5 結果}

5.1 アンケート結果

本アンケートの結果を項目ごとに集計し た。図2はキャラクターを好きになったき っかけと現在好きな理由の差異を集計し たものである．このカテゴリーを総合カテ ゴリーと名付ける，総合カテゴリーにおい て, 男女ともに, どの項目も誘因魅力より も継続魅力のほう数值が多いことが分か る.

図3はキャラクターの外見についての項 目を集計したものである.このカテゴリー を外見カテゴリーと名付ける. キャラクタ 一の外見に魅力を感じる要素がないとい う回答以外は, 誘因魅力より継続魅力の数 值が大きいことが分かる。

図 4 はキャラクターの内面についての 項目を集計したものである.このカテゴ リーを内面カテゴリーと名付ける。「な し」と「弱気」の項目以外は誘因魅力よ りも継続魅力のほうが数值が大きいこと が分かる。

\section{2 カイ二乗検定}

アンケートの結果から誘因魅力と継続魅 力に差異があることを確認するためにカイ 二乗検定を行った. 表 2 , 表 3, 表 4 はそれ ぞれ総合カテゴリー, 外見的要素, 外見 的要素の誘因魅力と継続魅力に対してカ イ二乗検定を行った結果である. 図機能の $\mathrm{p}$ 值が 0.1 以下ならば + , 0.05 以下ならば *，0.01 以下ならば ** で示している. 


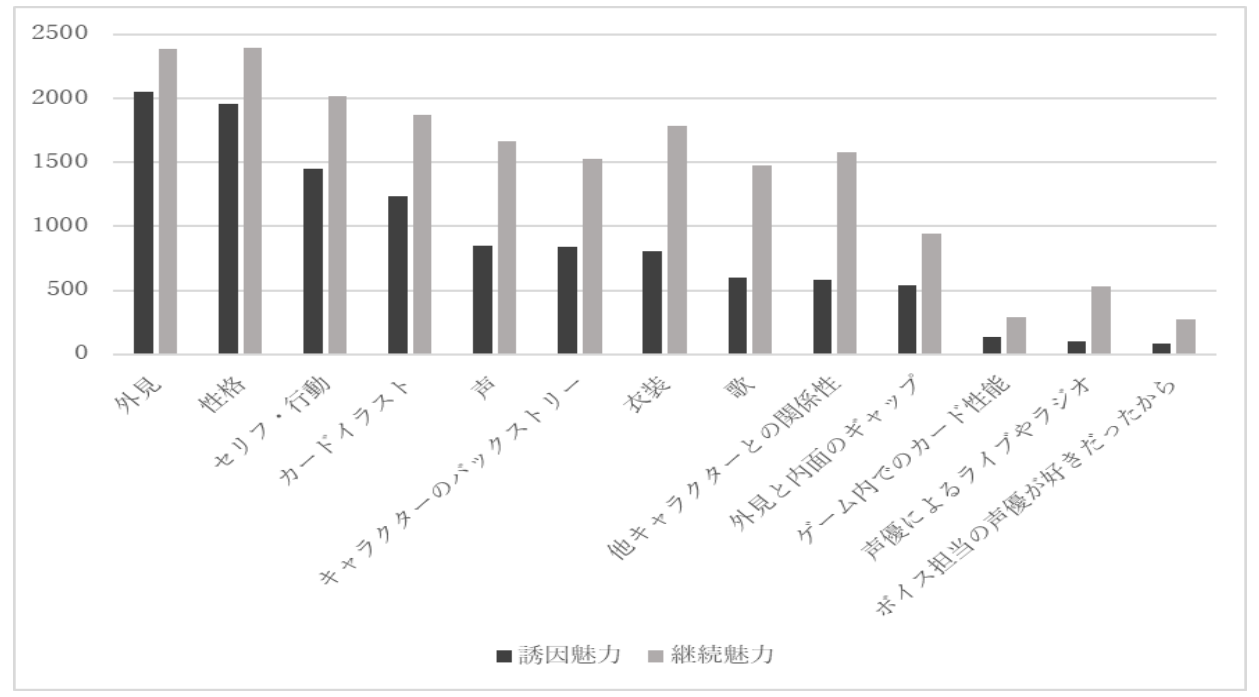

図 1 総合カテゴリーにおける誘因魅力と継続魅力の差

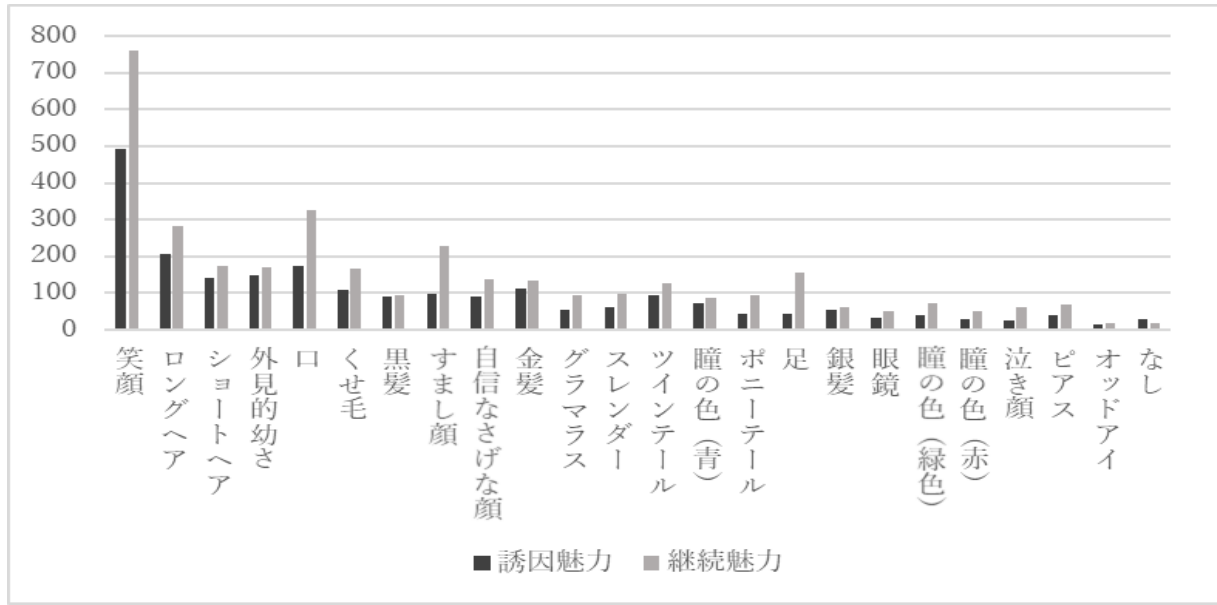

図 2 外見における誘因魅力と継続魅力の差

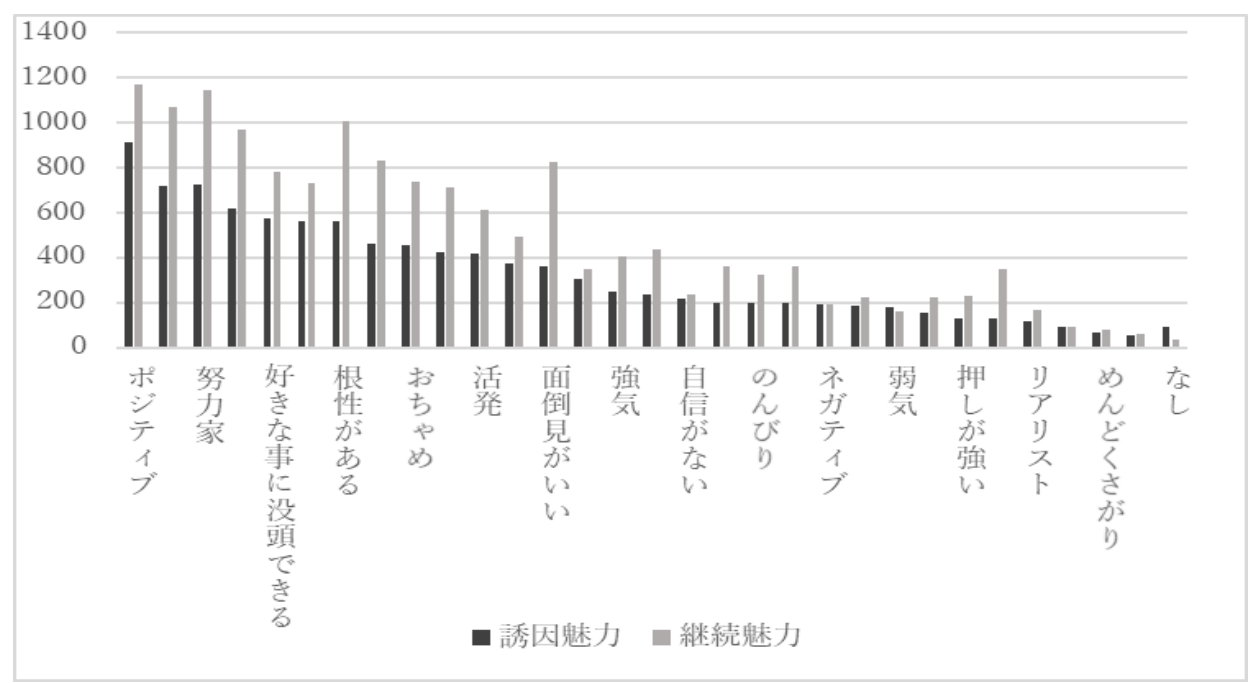

図 3 内面における誘因魅力と継続魅力の差 
表 2 総合カテゴリーにおける残差分析 の結果

\begin{tabular}{|l|c|c|}
\cline { 2 - 3 } \multicolumn{1}{c|}{} & 調整済み標準残差 & $\mathbf{p}$ 值 \\
\hline 外見 & 13.130 & $* *$ \\
\hline 性格 & 11.011 & $* *$ \\
\hline セリフ・行動 & 5.609 & $* *$ \\
\hline カードイラスト & 2.776 & $* *$ \\
\hline 声 & -3.942 & $* *$ \\
\hline バックストーリー & -2.092 & $*$ \\
\hline 衣装 & -7.038 & $* *$ \\
\hline 歌 & -8.303 & $* *$ \\
\hline 他キャラクターとの関 \\
係性
\end{tabular}

表 3-1 外見的要素の残差分析の結果

\begin{tabular}{|l|c|c|}
\cline { 2 - 3 } \multicolumn{1}{c|}{} & 調整済み標準残差 & $\mathrm{p}$ 值 \\
\hline 笑顔 & -0.025 & $\mathrm{~ns}$ \\
\hline ロングヘア & 1.706 & + \\
\hline ショートヘア & 2.957 & $* *$ \\
\hline 外見的幼さ & 3.283 & $* *$ \\
\hline 口 & -4.327 & $* *$ \\
\hline くせ毛 & 0.537 & $\mathrm{~ns}$ \\
\hline 黒髪 & 3.198 & $* *$ \\
\hline すまし顔 & -4.369 & $* *$ \\
\hline 自信なざな顔 & -0.968 & $\mathrm{~ns}$ \\
\hline 金髪 & 1.972 & $*$ \\
\hline グラマラス & 0.809 & $\mathrm{~ns}$ \\
\hline スレンダー & 0.356 & $\mathrm{~ns}$ \\
\hline ツインテール & 0.714 & $\mathrm{~ns}$ \\
\hline 瞳の色(青) & 1.658 & + \\
\hline ポニーテール & -1.767 & + \\
\hline 足 & -7.921 & $* *$ \\
\hline 銀髪 & 2.171 & $*$ \\
\hline 眼鏡 & 0.814 & $\mathrm{~ns}$ \\
\hline 瞳の色(緑色) & -0.869 & $\mathrm{~ns}$ \\
\hline 瞳の色(赤) & -0.343 & $\mathrm{~ns}$ \\
\hline 泣き顔 & -3.814 & $* *$ \\
\hline ピアス & -1.493 & $\mathrm{~ns}$ \\
\hline オッドアイ & 0.035 & $\mathrm{~ns}$ \\
\hline
\end{tabular}

\section{3 因子分析}

魅力を感じる要素の組み合わせを調べ るために, 2603 件のアンケート結果に対 して因子分析を行った。平行法を用いた 結果, 因子数は 41 となった. 表 5, 表 6,
表 7, 表 8, 表 9, 表 10 に因子分析の結 果の一部示す. 要素名で 1 とついている ものは好きになったきっかけの要素, 要 素名の後に 2 とついているものは現在好 きな理由の要素について示している.

表 4 内面的要素の残差分析の結果

\begin{tabular}{|l|c|c|}
\cline { 2 - 3 } \multicolumn{1}{l|}{} & 調整済み標準残差 & $\mathrm{p}$ 值 \\
\hline ポジティブ & 3.858 & $* *$ \\
\hline 強い信念 & 0.446 & $\mathrm{~ns}$ \\
\hline 努力家 & -0.822 & $\mathrm{~ns}$ \\
\hline まじめ & -0.697 & $\mathrm{~ns}$ \\
\hline 好きな事に没頭できる & 2.004 & $*$ \\
\hline 明るい & 2.777 & $* *$ \\
\hline 根性がある & -3.285 & $* *$ \\
\hline 自分の弱さと向き合え & -3.027 & $* *$ \\
る & & \\
\hline おちやめ & -1.066 & $\mathrm{~ns}$ \\
\hline 負けず嫌い & -1.698 & + \\
\hline 活発 & 0.510 & $\mathrm{~ns}$ \\
\hline 自由奔放 & 1.929 & + \\
\hline 面倒見がいい & -6.790 & $* *$ \\
\hline おっとり & 3.431 & $* *$ \\
\hline 強気 & -0.905 & $\mathrm{~ns}$ \\
\hline お姉さんキヤラ & -2.613 & $* *$ \\
\hline 自信がない & 3.496 & $* *$ \\
\hline 勝気 & -2.055 & $*$ \\
\hline のんびり & -0.833 & $\mathrm{~ns}$ \\
\hline いじられ役 & -2.163 & $*$ \\
\hline ネガティブ & 3.865 & $* *$ \\
\hline 恥ずかしがり屋 & 2.547 & $*$ \\
\hline 弱気 & 4.871 & $* *$ \\
\hline 弱みを見せない & 0.449 & $\mathrm{~ns}$ \\
\hline 押しが強い & -1.489 & $\mathrm{~ns}$ \\
\hline ツッコ役 & -5.990 & $* *$ \\
\hline リアリスト & 0.391 & $\mathrm{~ns}$ \\
\hline
\end{tabular}

\section{6 考察}

\section{1 誘因魅力と継続魅力の差について}

\section{1 .1 総合}

全体として，誘因魅力は「外見」・「性 格」・「セリフ・行動」・「カードイラスト」 が有意に多い. 継続魅力は「声」・「バッ クストーリー」・「衣装・歌」・「他キャラ クターとの関係性」・「カード性能」・「ラ 
イブやラジオ」・「ボイス担当の声優」が 有意に多い。キャラクターを知った時に 目に入りや寸いものが誘因魅力として, あとから知ることが多い要素や追加され ることが多い要素が継続魅力として出現 している.

表 5 因子分析の結果 1

\begin{tabular}{|c|c|c|c|}
\hline 要素名 & 因子 1 & 因子 2 & 因子 3 \\
\hline ネガティブ 2 & 0.69 & -0.11 & 0.11 \\
\hline ネガティブ 1 & 0.68 & -0.09 & 0.07 \\
\hline 自信がない 1 & 0.66 & 0.00 & -0.01 \\
\hline 自信がない 2 & 0.65 & 0.03 & -0.05 \\
\hline 弱気 1 & 0.64 & 0.02 & -0.04 \\
\hline 弱気 2 & 0.61 & 0.02 & 0.03 \\
\hline 自信なさげな顔 1 & 0.58 & 0.04 & 0.02 \\
\hline すぐへこたれる 2 & 0.55 & -0.06 & -0.05 \\
\hline すぐへこたれる 1 & 0.51 & -0.09 & -0.09 \\
\hline 自信なさげな顔 2 & 0.49 & 0.19 & 0.04 \\
\hline 泣き顔 1 & 0.33 & 0.04 & -0.01 \\
\hline 泣き顔 2 & 0.30 & 0.17 & 0.02 \\
\hline 背景 2 & 0.03 & 0.69 & 0.07 \\
\hline 衣装 2 & -0.02 & 0.61 & -0.09 \\
\hline イラスト 2 & 0.00 & 0.56 & 0.00 \\
\hline セリフ 2 & 0.05 & 0.52 & 0.00 \\
\hline 人間関係 2 & 0.04 & 0.51 & -0.06 \\
\hline 関連作品 2 & 0.03 & 0.42 & -0.10 \\
\hline 性能 2 & -0.05 & 0.36 & -0.08 \\
\hline ギヤップ 2 & -0.03 & 0.36 & -0.06 \\
\hline 性格 2 & -0.01 & 0.31 & 0.12 \\
\hline 努力家 1 & -0.04 & -0.15 & 0.81 \\
\hline 努力家 2 & -0.07 & 0.06 & 0.75 \\
\hline まじめ 2 & 0.02 & -0.01 & 0.72 \\
\hline まじめ 1 & 0.02 & -0.22 & 0.71 \\
\hline 強い信念 2 & -0.07 & 0.18 & 0.39 \\
\hline 根性がある 2 & -0.01 & 0.21 & 0.38 \\
\hline 根性がある 1 & 0.00 & -0.03 & 0.37 \\
\hline 強い信念 1 & -0.05 & -0.01 & 0.37 \\
\hline ライブ 2 & -0.06 & 0.37 & -0.08 \\
\hline 歌 2 & 0.05 & 0.38 & 0.05 \\
\hline
\end{tabular}

\section{1 .2 外見}

誘因魅力は「ショートヘア」・「外見的幼 さ」・黒髪」・「金髪」・「銀髪」が有意に多い. 継続魅力は「口」・「すまし顔」・「足」・「泣き 顔」が有意に多い. 男女ともに外見的な幼
さ・髪色・髪型が誘因魅力として出ており, ユーザーは幼い外見や髪型に魅力を感じ ていることが分かる. それに対して継続魅力 は口・足などの性的魅力を感じやすい項目 とすまし顔・泣き顔等の表情に関するものが 上がっており, キャラクターをよく見てから気 づく魅力や最初に見せていたものと別のも のを見せてくるものがあげられている.

表 6 因子分析の結果 2

\begin{tabular}{|c|c|c|c|}
\hline 要素名 & 因子 4 & 因子 5 & 因子 6 \\
\hline 勝気 1 & 0.91 & 0.08 & 0.06 \\
\hline 勝気 2 & 0.89 & 0.09 & 0.01 \\
\hline 強気 2 & 0.72 & 0.01 & 0.00 \\
\hline 強気 1 & 0.71 & 0.00 & 0.00 \\
\hline 負けず嫌い 1 & 0.35 & -0.14 & 0.00 \\
\hline 負けず嫌い 2 & 0.31 & -0.14 & 0.00 \\
\hline 押しが強い 2 & 0.15 & 0.08 & -0.05 \\
\hline 明るい 1 & 0.01 & 0.85 & 0.05 \\
\hline 明るい 2 & -0.02 & 0.81 & 0.02 \\
\hline 活発 2 & 0.10 & 0.60 & -0.01 \\
\hline 活発 1 & 0.09 & 0.59 & 0.01 \\
\hline ポジティブ 1 & 0.00 & 0.55 & 0.04 \\
\hline 笑顔 1 & -0.07 & 0.35 & -0.04 \\
\hline 笑顔 2 & -0.08 & 0.23 & 0.02 \\
\hline 内面と内面 2 & -0.03 & 0.05 & 0.01 \\
\hline 女性 & 0.05 & 0.04 & 1.05 \\
\hline 男性 & -0.06 & -0.05 & -1.05 \\
\hline ポジティブ 2 & 0.50 & 0.00 & 0.12 \\
\hline
\end{tabular}

表 7 因子分析の結果 3

\begin{tabular}{|c|c|c|c|}
\hline 要素名 & 因子 7 & 因子 8 & 因子 9 \\
\hline 背景 1 & 0.50 & -0.02 & -0.12 \\
\hline 人間関係 1 & 0.47 & 0.01 & -0.03 \\
\hline 性格 1 & 0.45 & 0.01 & -0.04 \\
\hline セリフ 1 & 0.40 & 0.02 & 0.01 \\
\hline ギャップ 1 & 0.29 & 0.11 & -0.02 \\
\hline 関連作品 1 & 0.13 & 0.00 & 0.02 \\
\hline 外面と真の顔 1 & 0.05 & 0.00 & 0.00 \\
\hline 銀髪 2 & 0.09 & 1.03 & -0.02 \\
\hline 銀髪 1 & 0.10 & 0.91 & -0.03 \\
\hline 口 2 & -0.17 & -0.01 & 0.94 \\
\hline 口 1 & -0.02 & -0.02 & 0.73 \\
\hline 足 2 & -0.09 & 0.00 & 0.35 \\
\hline 衣装 & 0.31 & 0.01 & 0.06 \\
\hline
\end{tabular}


表 8 因子分析の結果 4

\begin{tabular}{|c|c|c|c|}
\hline 要素名 & 因子 10 & 因子 11 & $\begin{array}{c}\text { 因子 } \\
12\end{array}$ \\
\hline リアリスト 1 & 1.03 & -0.07 & -0.13 \\
\hline リアリスト 2 & 0.85 & -0.04 & -0.10 \\
\hline お姉さんキャラ 2 & -0.07 & 0.83 & 0.00 \\
\hline お姉さんキャラ 1 & -0.03 & 0.78 & -0.02 \\
\hline 面倒見がいい 1 & 0.00 & 0.52 & -0.01 \\
\hline 面倒見がいい 2 & -0.01 & 0.51 & 0.02 \\
\hline スレンダー2 & -0.11 & -0.01 & 0.93 \\
\hline スレンダー1 & -0.09 & -0.01 & 0.87 \\
\hline
\end{tabular}

表 9 因子分析の結果 5

\begin{tabular}{l|c|cc}
\hline 要素名 & \multicolumn{1}{|c|}{ 因子 13} & 因子 14 & 因子 15 \\
\cline { 2 - 3 } 声優 2 & 0.51 & 0.01 & 0.02 \\
ライブ 1 & 0.47 & 0.00 & -0.03 \\
声優 1 & 0.47 & 0.00 & -0.02 \\
ライブ 2 & 0.42 & 0.03 & 0.01 \\
性能 1 & 0.15 & 0.02 & -0.03 \\
ショート 2 & 0.03 & 0.98 & 0.00 \\
ショート 1 & 0.04 & 0.90 & 0.02 \\
趣味に没頭 2 & -0.10 & -0.01 & 0.96 \\
趣味に没頭 1 & -0.03 & 0.03 & 0.85 \\
\cline { 3 - 3 }
\end{tabular}

表 10 因子分析の結果 6

\begin{tabular}{|c|c|c|c|}
\hline 要素名 & 因子 16 & 因子 17 & 因子 18 \\
\hline 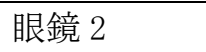 & 1.04 & -0.02 & -0.02 \\
\hline 眼鏡 1 & 0.83 & -0.02 & -0.04 \\
\hline 金髮 2 & -0.01 & 1.04 & -0.02 \\
\hline 金髪 1 & -0.03 & 0.82 & -0.01 \\
\hline 外見的幼さ 2 & -0.02 & -0.01 & 0.94 \\
\hline 外見的幼さ 1 & -0.04 & -0.02 & 0.92 \\
\hline
\end{tabular}

表 11 因子分析の結果 7

\begin{tabular}{|c|c|c|c|}
\hline 要素名 & 因子 19 & 因子 20 & 因子 21 \\
\hline グラマラス 2 & 0.99 & 0.02 & -0.02 \\
\hline グラマラス 1 & 0.86 & 0.01 & -0.04 \\
\hline おっとり 2 & 0.01 & 1.08 & 0.02 \\
\hline おっとり 1 & 0.02 & 0.72 & 0.00 \\
\hline オッドアイ 2 & -0.04 & 0.01 & 0.97 \\
\hline オッドアイ 1 & -0.03 & 0.02 & 0.85 \\
\hline
\end{tabular}

\subsection{3 内面}

誘因魅力は「ポジティブ」・「好きな事に 没頭できる」・「明るい」・自信がない」・掠
つとり」・「ネガティブ」・「恥ずかしがり

屋」・「弱気」・「ツンデレ」が有意に多い。 継続魅力は「根性がある」・「自分の弱さと 向き合える」・「面倒見がいい」・「お姉さん キャラ」・「強気」・「いじられ役」・「ツッコ ミ役」が有意に多い。誘因魅力として，庇 護欲を掻き立てる要素か元気で明るい要 素が重要であると推測できる。また，キャ ラクターをより魅力的に感じさせるため には他のキャラクターとの関係を強調し たり増やしたりする必要があると考えら れる。

表 12 因子分析の結果 8

\begin{tabular}{|c|c|c|c|}
\hline 要素名 & 因子 22 & 因子 23 & 因子 24 \\
\hline 自由奔放 2 & 0.87 & 0.02 & 0.04 \\
\hline 自由奔放 1 & 0.87 & 0.03 & 0.02 \\
\hline 押しが強い 1 & 0.12 & -0.01 & 0.02 \\
\hline 青目 2 & 0.06 & 0.95 & -0.06 \\
\hline 青目 1 & 0.02 & 0.91 & -0.03 \\
\hline 赤目 2 & 0.04 & -0.05 & 0.93 \\
\hline 赤目 1 & 0.05 & -0.03 & 0.90 \\
\hline
\end{tabular}

\section{2 因子分析の考察}

因子分析の結果，外見・内面に関して は誘因魅力と継続魅力で同じ要素を魅力 的だと感じているとわかる。一度魅力と 感じた要素は魅力を感じることがなく， 誘因魅力がそのまま継続魅力となると考 えられる。

第 2 因子から，あとからキャラクター に追加できる要素，キャラクターを知る ことによって気づく要素が継続魅力とし て有力であると考えられる。それに対し て誘因魅力は一度キャラクターの要素と して決めてしまうと変えられない要素が あげられている．継続的にキャラクター に魅力を感じさせるためには最初のキャ ラクター設定が重要であると推測できる.

また庇護欲を掻き立てるキャラクター, 
芯の強いキャラクター，ムードメーカー なキャラクターが魅力的だと感じるユー ザーが多く，モバイルゲームにおいて誘 因魅力・継続魅力共に一貫したキャラク ター性が大事であるといえる。

\section{7 結論}

\section{1 結論}

本研究では,『アイドルマスターシンデ レラガールズ』のファンにアンケート調 査を行い, その結果を用いてカイ二乗検 定と因子分析によってキャラクターの誘 因魅力と継続魅力の差と魅力的に感じる 要素の組み合わせを分析した. その結果, キャラクターを印象付けることができる 要素が誘因魅力, 後から追加することが 可能な要素が継続魅力であるということ が分かった。

モバイルゲームは運営されていく中で 様々な要素が追加され発展していく特徵 がある，そのため，誘因魅力は変えるこ とができない印象的な要素, 継続魅力は あとから追加できる要素が魅力的である ことは今後のモバイルゲームの発展に貢 献できるのではないかと考えられる.

\section{2 今後の課題}

本研究では『アイドルマスターシンデ レラガールズ』の一作品のみの分析を行 っているため，他のモバイルゲームで同 じ傾向が出るか定かではない. キャラク ターが少ない作品や，アイドル以外のキ ヤラクターが出る作品, もしくは男性ア イドルが出てくる作品等と比較し, その 他モバイルゲームと今回の結果にどのよ うな差異があるのか調べる必要がある.

\section{参考文献}

[1] 株式会社三菱総合研究所 :「スマホ ゲームに関するアンケート結果」

https://www.caa.go.jp/policies/policy/consu mer_policy/caution/internet/pdf/adjustments _index_1_160915_0004.pdf（閲覧日 : 2020 年 10 月 28 日).

[2] 三浦直是, 山本広志：「漫画の登場 人物の顔の分析」, 山形大学紀要 (教育科 学), vol.15, No.2, pp.213-223, 2010. [3] 河谷大和, 柏崎礼生, 高井昌彰, 高 井那美 :「アニメキャラクターの特徵抽 出に基づくアニメ度の評価」, 情報処理学 会研究報告グラフィクスと CDA（CG）, vol.80, pp35-38, 2018.

[4] 牟田淳：「キャラクターから感じる 印象の研究」, 東京工芸大学芸術学部紀要, vol.21, pp.27-40, 2015.

[5] 田中翔一, 山本博史：「フィクショ ン上のキャラクターに対する性格推定」, 情報処理学会関西支部大会論文集, 2016. [6]平田郁織：「少年漫画におけるキャ ラクターの魅力的な要素の分析」公立は こだて未来大学卒業論文, 2018.

[7] 『アイドルマスターシンデレラガー ルズスターライトステージ』 https://cinderella.idolmaster.jp/sl-stage/ (閲 覧日:2020 年 10 月 30 日).

[8] 『アイドルマスターシンデレラガー ルズ』 https://cinderella.idolmaster.jp/ (閲 覧日：2020年 10 月 30 日). 